\title{
Segmentation of quantity surveying professional services for focus strategy and diversification
}

\author{
Michael Adesi \\ Technological University Dublin, michael.adesi@tudublin.ie \\ De-Graft Owusu-Manu \\ Kwame Nkrumah University of Science and Technology \\ Frank Boateng \\ University of Mines and Technology, Tarkwa, Ghana
}

Follow this and additional works at: https://arrow.tudublin.ie/beschrecart

Part of the Business Administration, Management, and Operations Commons, Business Intelligence Commons, Management Sciences and Quantitative Methods Commons, and the Other Business Commons

\section{Recommended Citation}

Adesi, M., Owusu-Manu, D., \& Boateng, F. (2019). Segmentation of quantity surveying professional services for focus strategy and diversification. Journal of Financial Management of Property and Construction. DOI: 10.1108/jfmpc-09-2018-0052

This Article is brought to you for free and open access by the School of Surveying and Construction Management at ARROW@TU Dublin. It has been accepted for inclusion in Articles by an authorized administrator of ARROW@TU Dublin. For more information, please contact arrow.admin@tudublin.ie, aisling.coyne@tudublin.ie, gerard.connolly@tudublin.ie.

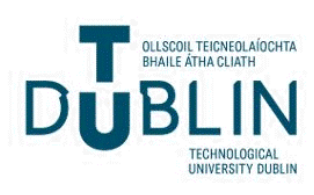


See discussions, stats, and author profiles for this publication at: https://www.researchgate.net/publication/335615292

\section{Segmentation of quantity surveying professional services for focus strategy and diversification}

Article in Journal of Financial Management of Property and Construction · August 2019 DOI: 10.1108/JMPC-09-2018-0052

CITATIONS

3 authors:

Michael Ades

Kwame Nkrumah University Of Science and Technology

14 PUBLICATIONS 56 CITATIONS

SEE PROFILE

Frank Boateng

University of Mines and Technology

18 PUBLICATIONS 32 CITATIONS

SEE PROFILE

Some of the authors of this publication are also working on these related projects:

Project Exploring Sustainable Considerations of Smart Cities in Developing Countries: The Case Study of Kumasi City View project

Project $\quad$ Fiduciary Responsibility of Gold Mining Companies to Stakeholders: The Case of Ghana Mining Industry View project
De-Graft Owusu-Manu

Kwame Nkrumah University Of Science and Technology

150 PUBLICATIONS 1,209 CITATIONS

SEE PROFILE 


\title{
Segmentation of quantity surveying professional services for focus strategy and diversification
}

\author{
Michael Adesi \\ Department of Quantity Surveying and Construction Economics, \\ Technological University Dublin, Dublin, Ireland \\ De-Graft Owusu-Manu \\ Department of Construction Technology and Management, \\ Kwame Nkrumah University of Science and Technology, Kumasi, Ghana, and \\ Frank Boateng \\ Department of Management Studies, \\ University of Mines and Technology, Tarkwa, Ghana
}

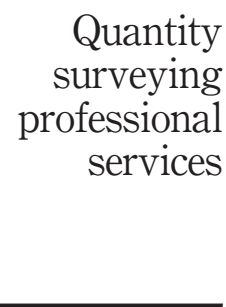

Received 14 September 2018 Revised 28 November 2018 9 February 2019 2 March 2019 Accepted 27 June 2019

\begin{abstract}
Purpose - Notwithstanding that numerous studies have focused on strategy in quantity surveying (QS) professional service firms, there is a paucity of investigation on the segmentation of QS professional services. The purpose of this study is to investigate the segmentation of QS services for diversification and a focus strategy formation.

Design/methodology/approach - This study adopts the positivist stance and quantitative approach in which a simple random sampling technique was used to select participants. In total, 110 survey questionnaires were administered to registered professional QS, out of which 79 completed questionnaires were returned for analysis.

Findings - The paper identifies three main QS service segments characterised by low, moderate and high competition. In addition, this study found that the concentration of traditional QS services in the building construction sector is due to the unwillingness of QS professional service firms to diversify into the nonconstruction sectors such as oil and gas. The diversification of QS services in the low competitive segment requires the adoption of agile approaches.

Research limitations/implications - The study was limited to numeric analyses and so would be complemented by qualitative research in the future.

Practical implications - This paper is useful to QS professional service firms interested in diversifying their services into the non-construction sectors to enhance the pricing of their services.

Originality/value - Segmentation of QS services is fundamental to the formulation of focus strategy for non-construction sectors such as oil and gas and mining to enhance the pricing of QS professional services.
\end{abstract}

Keywords Strategy, Management, Strategic management, Competitive advantage, Business strategy, Professional quantity surveyors, Diversification, Quantity, Surveying, Professional, Segmentation, Pricing

Paper type Research paper

Introduction

High level of competition in the business environment erodes the opportunities of quantity surveying (QS) firms (Abidin et al., 2014; Ofori and Toor, 2012). Professional QS firms
Journal of Financial Management of Property and Construction of Property and Construction
(c) Emerald Publishing Limited 1366-4387 DOI 10.1108/JFMPC-09-2018-0052 
respond to intense competition by engaging in unethical practices during service delivery to clients. These unethical practices include under-pricing of services; conflict of interest; divulging of trade secrets and denial of fault to survive in a competitive business environment (Olatunji, 2007; Olatunji and Ogunsemi, 2006; and Smith, 2004). QS firms that offer traditional services to clients face intense competition because over-concentration of firms creates a "red ocean" market segment (Kim et al., 2008, p. 522). A red ocean market segment characterised by a high level of competition, and low-profit margin (Kim and Mauborgne, 2015) makes it difficult for QS firms to survive. In addition to the high level of competition, QS firms are facing various challenges in turbulent business environment because of difficult economic conditions; lack of access to finance and credit and rapidly changing technology (Kaklauskas et al., 2011; Frei, 2010). Turbulent business environment affects the performance, profitability and survival of QS firms operating in the overconcentrated market segment. Thus, diversification of non-traditional QS services into nonconstruction sectors such as oil and gas and mining ensures the survival and profitability of QS firms.

Diversification is a corporate level strategy that firms use to seize opportunities in new markets segments to improve their performance, growth, survival and access to capital (Jang, 2012). In addition, earlier studies by Andrews (1980) and Gluck (1985) defined diversification as a strategy for expanding the core business activities of organisations into new market segments. Furthermore, diversification is key to strategy formation in organisations. Studies by Ansoff (1958) and Rumelt (1974) focused on the models of diversification and its impacts on the value of firms. A study by Ganiyu et al. (2012) on the diversification and performance of QS firms concludes that diversification increases the knowledge of QS professionals. Despite this conclusion, Ganiyu et al. (2012) did not consider the specific market segments and sectors for QS services diversification.

The demand for traditional QS services has reduced over the last three decades. For instance, the demand for preparation of bills of quantities that accounted for 80 per cent of QS services in the 1980s reduced to 10 per cent in 2003 (Smith, 2004). Despite the fact that the demand for traditional QS services continue to decrease, opportunities exist in the nonconstruction sectors. Therefore, the low concentration of non-traditional QS services in the non-construction sectors provides opportunities for QS to use a focus strategy to drive the diversification of their services. The aim of this study is to investigate QS professional services and classify them into appropriate segments to ensure the diversification of QS professional services.

\section{Literature review}

This section of the paper focuses on the review of existing literature on QS professional services; non-traditional services and focus strategy in QS practices.

\section{Quantity surveying professional services}

Quantity surveyors provide different types of services to clients in different industries (Olanrewaju and Anahve, 2015) at the various stages of construction projects. For instance, QS professionals provide cost management services throughout the life cycle of construction projects to ensure financial accountability, transparency and value for money (Olanrewaju and Anahve, 2015). Olawale (2006) classifies QS professional services by highlighting emerging services such as alternative dispute resolution (ADR). Olatunde (2006) categorises QS services using the pre-contract, contract and post contract stages as a criteria. QS professional services are classified based on the roles of quantity surveyors at various stages of construction project delivery. For instance, contract management, construction 
procurement management and life cycle costing are categorised as contract procurement management services.

Burnside and Westcott (1999) and Seeley (1997) classify QS services as traditional and non-traditional services. Traditional QS services refer to the category of technical and professional services that are accredited and regulated by recognised QS professional bodies (Burnside and Westcott, 1999). According to Seeley (1997), traditional QS services include preparation of tender documents, measurement and valuation of variations, preparation of final accounts, valuing work in progress and contract administration. The Canadian Institute of Quantity Surveyors (2002) classifies traditional QS services into cost consulting, mortgage monitoring, life cycle costing and value management. These classifications of QS services enable QS professional bodies and third level institutions to develop training programmes that address the skills requirements of QS firms. While traditional QS services receive significant attention in scholarly investigations, non-traditional QS services receive far less attention in that regard. Thus, this paper examines non-traditional QS services below.

\section{Non-traditional services}

The complex nature of the construction industry (Ofori and Toor, 2012) has resulted in the emergence of non-traditional QS services. In addition, the increasing demand for nontraditional QS services has led to the emergence of contemporary roles of quantity surveyors in both construction and non-construction sectors (Owusu-Manu et al., 2014). Usually, clients in non-construction sector require the services of QS professionals to undertake core business activities (Cartlidge, 2009). In the banking and financial sector, quantity surveyors offer bank monitoring services by providing impartial advice to banks on proposed construction projects. However, QS firms are unable to provide most of their services to clients in the non-construction sector (Smith, 2004) because of the lack of focus on the nonconstruction sector. An analysis of previous studies indicates that the contribution of nontraditional services to the income of QS firms has been increasing since 2003 from 10 per cent in 1995 to 50 per cent of the total income generated (Smith, 2004). To increase the level of their income generation, QS firms require a focus strategy that drives the diversification of their services.

\section{Focus strategy}

Focus strategy deals with the concentration of services or products in a market segment (Littler, 2015; Weber and Polo, 2010). According to Porter (1989), a focus strategy is suitable for developing market segments that provide services to the satisfaction of clients. Subsequently, clients' satisfaction leads to long-term relationship and repeat business (Taylor, 2005), which are necessary for competitive advantage in a market segment with many substitutes. Tanwar (2013) notes that fewer substitutes create a competitive advantage for firms operating in a niche market. Therefore, firms that intend to develop the focus strategy must identify and invest in the market segments with fewer substitutes (Cao and Gruca, 2005; Alba et al., 1997; Treacy and Wiersema, 1993). Furthermore, it is necessary for firms to consider the factors that influence the formation of focus strategy such as buyer group; product line and geographical market (Porter, 1986). In this study, a product line represents the QS services market segment with limited supply, while buyer groups represent different types of clients in a particular QS services market segment. The geographical market in this study represents the construction and non-construction sectors. The success of a focus strategy depends on the long-term vision of the firm; delegation of 
authority during decision-making; client-relationship management and expertise of professionals (Weber and Polo, 2010; Treacy and Wiersema, 1995).

\section{Focus strategy in quantity surveying professional service firms}

Focus strategy enables QS firms to capture a considerable number of clients to become leaders in a particular market segment. Innovative communication and service delivery enhance the relationship between the client and QS firms (Waller et al., 2000; Anderson et al., 1994), which leads to differentiation of services and repeat business (Jennings and Betts, 1996). Despite the importance of differentiation to focus strategy formation, Cheah et al. (2007) note that large financial requirement for differentiation makes it difficult for smaller QS firms to undertake new projects. However, the use of digital technologies and effective networking reduce the financial difficulties associated with differentiation in small and medium QS firms. Therefore, large financial requirements must not be an obstacle to differentiation and focus strategy formulation in small and medium QS firms.

\section{Methodology}

The choice of a research methodology depends on the philosophical stance of the researcher (Sexton, 2007). This study adopts the positivist stance and deductive reasoning that culminates into the use of the quantitative approach. The quantitative approach involves the use of numbers and statistical procedures to collect and analyse data (Naoum, 2013). A survey questionnaire comprising closed-ended questions with a series of scales of measurement was used to collect data from respondents. The choice of survey questionnaire for data collection was to ensure the validity and reliability of the information gathered (Ameyaw et al., 2017; Opoku et al., 2016; Hoxley, 2008). A pilot study was undertaken by administering the survey questionnaires to 16 research experts comprising 8 academics, and $8 \mathrm{QS}$ practitioners that led to the refinement of the questionnaire in terms of clarity; choice of words; speed of completion and suitability of variables. The survey questionnaire was in three sections, namely, respondents' profile, sectors of operation and QS services provided to clients. The third section consists of QS services gleaned from the literature review on QS services, as shown in Table I.

A five-point Likert scale was used to measure the variables shown in Table I with the following response options: $1=$ not competitive; 2 = Less competitive; 3 = moderately competitive; $4=$ competitive and $5=$ highly competitive. To ascertain the reliability of the Likert scale, a Cronbach alpha test for variables in Table I gave 0.90. The Cronbach alpha value is between 0 and 1 . The value closer to 1 , indicates a high degree of reliability of scale of measurement. Hence, the Cronbach alpha value of 0.90 shows that the scale of measurement is highly reliable for the measurement of the variables in Table I. Investigations by Aghimien et al. (2018) and Oke (2018) yielded Cronbach alpha values of $0.93,0.81$ and 0.92 , respectively. The study focused on a target population of 372 registered quantity surveyors of the Ghana Institution of Surveyors (GhIS). The participants consisted of 37 fellows; 282 professionals and 53 technicians. The target population of 372 is similar to the number of participants involved in existing studies by Ling et al. (2018) and Aghimien et al. (2018) in Singapore and Nigeria with target participants of 430 and 330, respectively. The GhIS was established by the Royal Institute of Chartered Surveyors in 1969.The GhIS operates under the laws of Ghana as a professional body for assessing, training, certifying and regulating professional QS practice in Ghana. Ghana is a thriving sub-Saharan country located in West Africa with a population of 29 million. The economy of Ghana is marketbased with significant growth opportunities in the services and agricultural sectors. The construction industry contributes 13.7 per cent to the gross domestic product of Ghana and 


\begin{tabular}{|c|c|c|}
\hline Variables & Sources & antit \\
\hline $\begin{array}{l}\text { Preparing tender documents } \\
\text { Interim valuations and payments } \\
\text { Valuation of construction work } \\
\text { Valuation of variations } \\
\text { Cost control of projects } \\
\text { Final account preparation and agreement } \\
\text { Claims preparation } \\
\text { Financial statements } \\
\text { Cost planning and cost checking } \\
\text { Advice on contracting methods } \\
\text { Preliminary cost advice } \\
\text { Contract administration } \\
\text { Preparing cash flow forecasts } \\
\text { Negotiating contract prices } \\
\text { Project management } \\
\text { Value management } \\
\text { Arbitrations and disputes resolution } \\
\text { Advice on procurement strategy } \\
\text { Construction management } \\
\text { Program management } \\
\text { Facilities management } \\
\text { Maintenance management } \\
\text { Whole life cycle cost management } \\
\text { Business planning } \\
\text { Risk management } \\
\text { Commercial management } \\
\text { Management of capital expenditure }\end{array}$ & $\begin{array}{l}\text { Burnside and Westcott (1999) } \\
\text { Owusu-Manu et al. (2014) } \\
\text { Ofori and Toor (2012) } \\
\text { Olanrewaju and Anahve (2015) } \\
\text { Olatunde (2006) } \\
\text { Cartlidge (2009) }\end{array}$ & $\begin{array}{r}\text { Table I. } \\
\text { List of variables } \\
\text { and sources }\end{array}$ \\
\hline
\end{tabular}

employs about 320,000 people (Ghana Statistical Service, 2017; Darko and Löwe, 2016). Having defined the target population and the scope of the study, the Kish (1965) formula was used to determine the sample size of the study. The Kish formula has been used in studies by Ashmawi et al. (2018), Adesi (2014) and Bolstein and Crow (2008) to determine the sample size for their investigation. Thus, the Kish formula is stated as follows:

$$
\mathrm{n}=\frac{\mathrm{n}^{1}}{1+\mathrm{n}^{1} / \mathrm{N}}
$$

From the Kish formula above, $n$ represents the sample size to be determined and $\mathrm{N}$ depicts the total number of the target population. To obtain the value of $\mathrm{n}^{1}$, the standard deviation at a confidence interval of 95 per cent was divided by the standard error of the distribution at 5 per cent. Thus, with these parameters, the Kish formula gave a sample size of 79 respondents. The simple random sampling technique was used to select the 79 respondents from the target population of 372 quantity surveyors because of the availability of a list of quantity surveyors registered with GhIS. Lette et al. (2018) used the simple random sampling technique in their investigation of work-related injuries among construction workers. A self-completed questionnaire was administered to 110 respondents through an internet-mediated online survey in which 79 usable responses were received for analysis. The main tools for data analysis were the descriptive statistics and competitive index (CI). Porter (2000) and Sala-i-Martin et al. (2004) developed the Global Competitiveness Index for 
categorising countries into high, middle and low stages of development, which was adapted for the segmentation of QS services shown in Table IV of this study. Based on Sala-i-Martin et al. (2015) and Underwood (2013), the CI was computed as follows:

$$
\mathrm{CI}=\frac{\sum_{\mathrm{i}=1}^{\mathrm{n}} \mathrm{x}_{\mathrm{i}}, \quad \mathrm{i}=1,2, \ldots, \mathrm{n}}{(\mathrm{A} * \mathrm{~N})} .
$$

Drawing from the CI expression, $n$ represents the variables associated with a question, $i$ denotes the response of participants from the first respondent $i=1$ through to the last respondent; A denotes the highest response rating on the Likert scale, i.e. 5 and $\mathrm{N}$ represents the total number of responsive participants in the study.

\section{Results from data analysis}

This section of the study presents the results of the data analysis on the profile of respondents; sectors of operation and QS services segmentation. The profile of respondents focused on the legal status of QS firms involved in the study; the number of years in operation; the rate of work acquisition and sectors of operation in Table II below.

The results in Table II above show that 12 per cent of respondents involved in the study are sole practitioners. In addition, QS firms operating as a private limited company employ 56 per cent of respondents. Similarly, 17 per cent of respondents work in QS firms that are into partnership, and 15 per cent of participants belong to QS organisations operating as consultants for government institutions. The results show that 38 per cent of the QS firms have been in existence for less than 10 years, while 37 per cent of QS firms involved in the study have been operating for 10-20 years. Similarly, 9 per cent of the firms that participated in the study have been in existence for 21-30 years, while 16 per cent of QS firms have been operating for over 30 years. Concerning the rate of work acquisition, Table II shows that 42

\begin{tabular}{lcr}
\hline Profile of firms & No. of respondents & $(\%)$ \\
\hline Legal status & & \\
i. Sole proprietorship & 10 & 12 \\
ii. Private limited company & 44 & 56 \\
iii. Partnership & 13 & 16 \\
iv. Others & 12 & 15 \\
Total & 79 & 100 \\
Age & & \\
i. Under 10 years & 30 & 38 \\
ii. 10-20 years & 29 & 37 \\
iii. 21-30 years & 7 & 9 \\
iv over 30 years & 13 & 16 \\
Total & 79 & 100 \\
Rate of work acquisition & & 10 \\
i. Not frequent & 8 & 33 \\
ii. Moderately frequent & 26 & 42 \\
iii. Frequent & 33 & 15 \\
iv. Very frequent & 12 & 100 \\
Total & 79 &
\end{tabular}

Table II.

Profile of respondents 
per cent of QS firms frequently acquire works, while 15 per cent of QS firms acquire works very frequently. Furthermore, Table II shows that 33 per cent of QS firms in the study have a moderate rate of work acquisition, while 10 per cent of firms do not acquire work frequently. The study seeks to ascertain the various sectors of operation for QS firms involved in the study. These sectors include the building construction; civil engineering; mechanical engineering services; oil and gas; mining and urban planning, as shown Table III.

The results in Table III above show that majority of QS firms representing 82.3 per cent seldom operate in the mining sector despite opportunities existing in the mining sector for the diversification of QS services. Similarly, 86 per cent of QS practices do not explore and exploit opportunities in the oil and gas sector by offering services to clients. In Table III, 58 per cent of respondents do not frequently operate in the mechanical engineering services sector. These results of Table III show that it is important to use a criterion for the segmentation of QS services; hence, this paper use competition as a criterion for segmentation of QS services in Table IV.

Drawing from Table IV, the highly competitive QS service segment consists of traditional QS services offered to clients within the building construction sector, suggesting a concentration of traditional QS services in the building construction sector. Moderate competitive QS services market segment comprising contract price negotiation; project management and value management services are shown in Table IV. Similarly, Table IV shows that the low competitive market segment consists of eleven (11) QS services that are rarely offered to clients by QS firms.

\section{Discussion of results}

The result of the study in Table II shows that most QS firms operate as private limited companies. The legal character of a firm determines the ownership structure and the types of activities undertaken (Owusu-Manu et al., 2010). According to Teece (1996), the ownership structure of a firm is related to the type of innovation, technology and policy adopted to ensure competitive advantage. The experience of a firm depends on its age and the ability to mobilise resources for service delivery to clients. Furthermore, a firm's age influences its performance, profitability and knowledge acquisition (Pervan et al., 2017). The knowledge of QS firms in professional service delivery enables them to make decisions that support the formation of a focus strategy for a particular market segment. In addition, the results show that a considerable number of firms involved in this study have been in existence for less than twenty years. This indicates that QS

\begin{tabular}{|c|c|c|c|c|c|c|c|}
\hline Sectors & $\begin{array}{c}\text { Not } \\
\text { frequent }(\%)\end{array}$ & $\begin{array}{c}\text { Less } \\
\text { frequent }(\%)\end{array}$ & $\begin{array}{l}\text { Responses } \\
\text { Moderately } \\
\text { frequent (\%) }\end{array}$ & $\begin{array}{l}\text { Frequent } \\
\qquad(\%)\end{array}$ & $\begin{array}{c}\text { Very } \\
\text { frequent }(\%)\end{array}$ & $\begin{array}{c}\text { Total } \\
(\%)\end{array}$ & \\
\hline 1. Building construction & 3.8 & 5.1 & 29.1 & 35.4 & 26.6 & 100 & \\
\hline 2. Civil engineering & 11.4 & 29.1 & 38.0 & 15.2 & 6.3 & 100 & \\
\hline 3. Mechanical engineering & & & & & & & Table III. \\
\hline services & 58.2 & 30.4 & 6.3 & 5.1 & 0.0 & 100 & f operation \\
\hline 4. Oil and gas & 86.1 & 8.9 & 1.3 & 3.7 & 0.0 & 100 & ol operation \\
\hline 5. Mining & 82.3 & 10.1 & 1.3 & 1.2 & 5.1 & 100 & \\
\hline 6. Urban planning & 38 & 34.2 & 19.0 & 6.3 & 2.5 & 100 & \\
\hline
\end{tabular}

Quantity surveying professional services

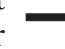


JFMPC

\begin{tabular}{|c|c|c|c|c|c|}
\hline Segment name and QS services & $N$ & Sum* & Competitive index & Ranking & Missing** \\
\hline \multicolumn{6}{|l|}{ High competition } \\
\hline 1. Preparing tender documents & 79 & 318 & 0.81 & 1 & \\
\hline 2. Interim valuations and payments & 79 & 308 & 0.78 & 2 & \\
\hline 3. Valuation of construction work & 79 & 306 & 0.77 & 3 & \\
\hline 4. Valuation of variations & 79 & 301 & 0.76 & 4 & \\
\hline 5. Cost control of projects & 79 & 296 & 0.75 & 5 & \\
\hline 6. Final account preparation and agreement & 79 & 296 & 0.75 & 5 & \\
\hline 7. Claims preparation & 79 & 286 & 0.72 & 6 & \\
\hline 8. Financial statements & 79 & 285 & 0.72 & 6 & \\
\hline 9. Cost planning and cost checking & 79 & 280 & 0.71 & 7 & \\
\hline 10. Advice on contracting methods & 79 & 279 & 0.71 & 7 & \\
\hline 11. Preliminary cost advice & 79 & 278 & 0.70 & 8 & \\
\hline 12. Contract administration & 78 & 274 & 0.70 & 8 & \\
\hline 13. Preparing cash flow forecasts & 79 & 273 & 0.69 & 9 & \\
\hline \multicolumn{6}{|l|}{ Moderate competition } \\
\hline 14. Negotiating contract prices & 79 & 260 & 0.66 & 10 & \\
\hline 15. Project management & 79 & 248 & 0.63 & 11 & \\
\hline 16. Value management & 79 & 239 & 0.61 & 12 & \\
\hline \multicolumn{6}{|l|}{ Low competition } \\
\hline 17. $\mathrm{ADR}$ & 79 & 183 & 0.46 & 13 & \\
\hline 18. Advice on procurement strategy & 78 & 175 & 0.45 & 14 & 1 \\
\hline 19. Construction management & 78 & 168 & 0.44 & 15 & 1 \\
\hline 20. Program management & 78 & 167 & 0.43 & 16 & 1 \\
\hline 21. Facilities management & 78 & 169 & 0.43 & 16 & 1 \\
\hline 22. Maintenance management & 78 & 166 & 0.43 & 16 & 1 \\
\hline 23. Whole life cycle cost management & 78 & 152 & 0.39 & 17 & 1 \\
\hline 24. Business planning & 78 & 151 & 0.39 & 17 & 1 \\
\hline 25. Risk management & 78 & 151 & 0.39 & 17 & 1 \\
\hline 26. Commercial management & 78 & 150 & 0.38 & 18 & 1 \\
\hline 27. Management of capital expenditure & 78 & 146 & 0.37 & 19 & 1 \\
\hline
\end{tabular}

Table IV.

Notes: *Sum of rating ranging from 1-5 assigned to each variable multiply by the number of respondents; QS services segments **Missing: represents the number of respondents who skipped the rating of these QS services

firms that have been in existence for more than ten years have considerable experience and knowledge about the QS market.

The rate of work acquisition by QS professional service firms is important for skill development and experience. For instance, Lee et al. (2013) highlighted the role of experience in career development and lifelong learning among QS professionals. Similarly, work acquisition improves the professional experience and knowledge acquisition of graduates entering the QS profession. The results on the rate of work acquisition show that QS firms with a high rate of work acquisition are able to provide opportunities for career and skills development than QS firms with a moderate and low rate of work acquisition. In addition, the result indicates that diversification into the nonconstruction sectors increases the rate of work acquisition for QS firms. Studies by Mzyece et al. (2010) and Hanid et al. (2007) on QS professional service in construction and non-construction sectors show that the non-construction sector has considerable opportunities for diversification. 
Mining and construction industry are closely related because mining operations require the services of construction professionals such as quantity surveyors. Construction activities in the mining sector such as site excavation; bulk material handling; construction of access roads and pad construction offer opportunities to QS practices. However, the result in Table III shows that QS professional service firms are unable to diversify their services into the mining sector because they continue to focus on building construction sector. Less concentration of QS service firms in the mining sector provides an opportunity for diversification. This implies that the mining sector remains an uncontested market segment or "blue ocean" (Kim and Mauborgne, 2014, p. 4) for QS service firms. The diversification of QS services such as value engineering; procurement services; cost control; estimation; feasibility studies; construction management and commercial management (Hanid et al., 2007) into the mining sector addresses the existing challenges in that sector. These challenges include cost, time and budget overruns; overpricing and underpricing of projects and professional services and disputes related to claims.

The oil discovery in Ghana provided QS firms with opportunity to diversify their services to support operations such as drilling and engineering in the oil and gas industry (Addai et al., 2009). According to Ajator (2014), QS services in the oil and gas sector include cost engineering and estimating services; procurement, contracting and commercial management; value management and facilities management. However, the results of this study suggest that QS practices seldom offer services to clients in the oil and gas sector. This means the oil and gas sector is uncontested and less saturated with QS firms. The success of QS services diversification in to the oil and gas sector of Ghana requires a focus strategy to create competitive advantage. A focus strategy enables QS practices to provide differentiated services in order to meet the expectations of clients in the oil and gas sector.

\section{Construction-related sectors}

The results in Table III show that a high concentration of QS firms in the building construction sector will erode competitive advantage. Therefore, QS firms must diversify their services into non-construction sectors such as oil and gas and mining using a focus strategy to drive the differentiation and provision of services to clients at low cost. Similarly, the results in Table III indicate that half of the respondents involved in the study do not provide services to clients in the mechanical engineering sector. This shows that the mechanical engineering sector is less saturated with QS firms than the building construction and the civil engineering sectors.

The reasons for a moderate concentration of QS practices in the civil engineering sector is because of the availability of civil engineering standard method of measurement (Seeley and Murray, 2001) and training of civil engineers in cost management and estimation (Adelil and $\mathrm{Wu}, 1998)$. In addition, the results in Table III suggest that it is not profitable for QS practices to focus on the provision of services in the civil engineering sector because it is in the moderately competitive market segment. Rapid technological changes have enhanced project and service delivery to clients. As a result of increasing competition, QS firms need to formulate strategies that focus on less saturated but profitable segments of both construction and non-construction sectors to create competitive advantage. In this study, QS professional services were categorised into segments based on the level of competition among QS firms. Previous studies examined the increasing level of competition among QS practitioners without considering competition as a criterion for the segmentation of the QS services. The choice of competition as a criterion for segmentation of QS services is consistent with Lin's (2002) suggestion for the selection of variables for segmentation. 
Furthermore, investigations by Drew et al. (2001) and Rahim et al. (2013) found high competition among QS practitioners. Highly competitive QS market segments have low profitability because of fee cutting to win more contracts than their rivals. Despite the emphasis on the use of information technology to create a competitive strategy, Jennings and Betts (1996) did not consider the segmentation of QS services as shown in Table IV of this study. The success of QS firms operating in highly competitive QS segment depends on the use of digital technologies such as building information modelling; data analytics and cloud computing to provide low-cost services to clients. QS firms that intend to diversify into the moderately competitive QS service segment must develop focus strategies that address the needs of clients and strategically position themselves in the market segment to make a profit (Larsen, 2010). The low competitive QS service segment suggests less saturation of QS firms and the availability of opportunities for diversification. It is important for QS firms to forecast the demand for their services in the three main QS service segments in Table IV before diversification. An analysis of the results reveals key issues regarding low competitive segment; high competitive segment; building construction and non-traditional sectors, as shown in Figure 1.

Drawing from Figure 1, it is important to highlight four main issues arising from this study. First, QS firms that operate in the building construction sector provide only services in the highly competitive segment and do not diversify. Second, QS firms can operate in more than one service segment identified in Table IV using the focus strategy with flexibility. Third, QS firms that intend to diversify their services in the highly competitive segment to less concentrated sectors such as oil and gas and mining must use focus strategy with agility to capture opportunities before their competitors begin to enter the potential market segments. Finally, the low competitive QS service segment has a better prospect for diversification in non-construction sectors such as mining, oil and gas. The high

Figure 1.

QS services segments for diversification

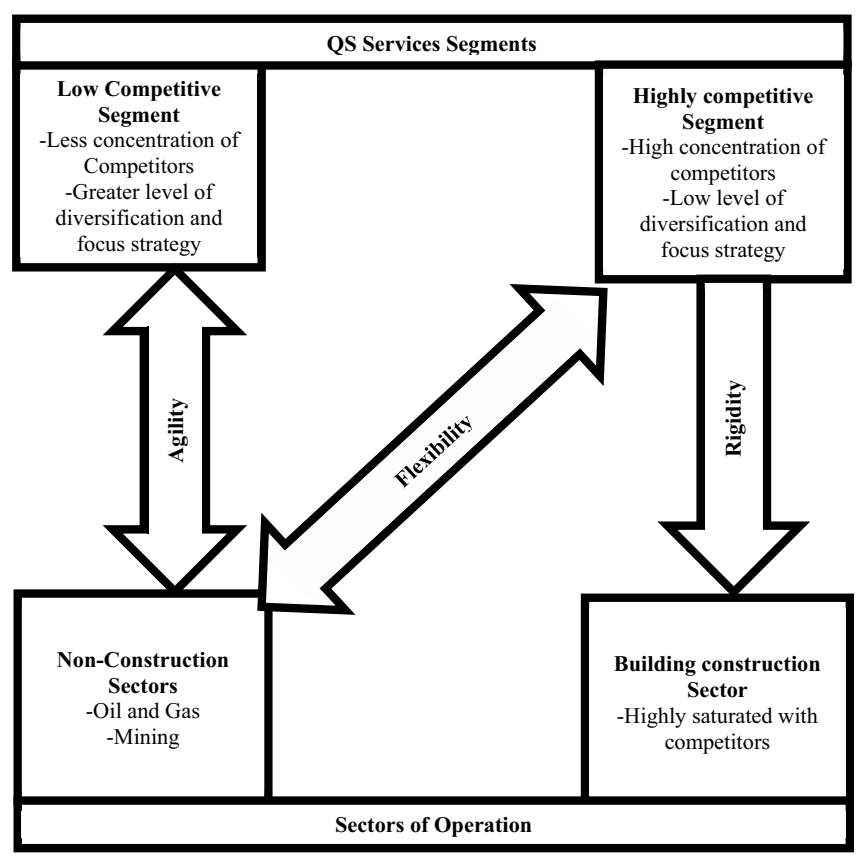


concentration of firms in the highly competitive segment, as shown in Figure 1, is because of the rigidity of QS firms to diversify into less saturated service segments. The rigidity QS to diversify into the non-construction sector is because of the lack of strategic vision to explore opportunities in new market segments and sectors despite the risks and threats associated with operating in highly competitive QS service segment. Drawing from Figure 1, QS firms require strategic agility and flexibility to effectively operate in the low competitive segment in non-traditional sectors such as mining and oil and gas.

\section{Conclusion}

The diversification of QS professional services in both construction and non-construction sectors is fundamental for developing a focus strategy that enhances competitive advantage and pricing. Increasing competition and globalisation underscore the importance of focus strategies especially for diversification of QS professional services. However, the inability of QS firms to diversify their services creates a high level of competition in the building construction sector. The segmentation of the QS professional services enables strategists in QS firms to select the most profitable segments for diversification during the formulation of focus strategy. Critical sectors identified by the study for diversification of QS services include mining, oil and gas and mechanical and engineering. At the initial stages of the diversification, it is important to collaborate with firms already operating in the QS service segment targeted for diversification. This provides access to inter-organisational resources to reduce the cost of diversifying QS services. Despite the contribution of this study to the diversification and segmentation of QS services, further research focusing on the diversification of non-traditional QS services will provide significant benefits to QS professional service firms. Thus, key areas for further studies include:

- environmental analysis for non-construction sectors for successful diversification;

- exploring and developing strategies for partnering and alliancing of QS professional service firms in diversified sectors such as mining; and

- investigating organisational ambidexterity in QS practices for diversification in non-traditional sectors.

Diversification of QS services will improve the performance and survival of QS firms operating highly saturated QS services market segments. The diversification of QS firms into non-traditional sectors leads to the creation of more jobs and increased revenue through tax.

\section{References}

Abidin, N.Z., Adros, N.A. and Hassan, H. (2014), "Competitive strategy and performance of quantity surveying firms in Malaysia", Journal of Construction in Developing Countries, Vol. 19 No. 2, p. 15.

Addai, J.P., Nkuah, M. and Amoah, P. (2009), "The Ghanaian quantity surveying and the emerging oil and gas industry", The Quantity Surveyor, Vol. 2, pp. 7-16.

Adelil, H. and Wu, M. (1998), "Regularization neural network for construction cost estimation", Journal of Construction Engineering and Management, Vol. 124 No. 1, pp. 18-24.

Adesi, M. (2014), "A generic framework for consultancy services pricing in Ghana: the case of quantity surveying practice", A Dissertation Submitted to the Kwame Nkrumah University of Science and Technology, available at: http://dspace.knust.edu.gh/handle/123456789/6858 (accessed 11 November 2018). 
Aghimien, D.O., Oke, A.E. and Aigbavboa, C.O. (2018), "Barriers to the adoption of value management in developing countries", Engineering, Construction and Architectural Management, Vol. 25 No. 7, pp. 818-834.

Ajator, U.O. (2014), "Costing of oil and gas projects for efficient management and sustainability", Journal of Environmental Science, Toxicology and Food Technology, Vol. 8 No. 1, pp. 70-84.

Alba, J., Lutz, R., Lynch, J., Sawyer, A., Weitz, B. and Wood, S. (1997), "Interactive home shopping: consumer, retailer, and manufacturer incentives to participate in electronic marketplaces", Journal of Marketing, Vol. 61 No. 3, pp. 38-53.

Ameyaw, E.E., Pärn, E.A., Chan, A.P.C., Owusu-Manu, D., Edwards, D.J. and Darko, A. (2017), “Corrupt practices in the construction industry: survey of Ghanaian experience", Journal of Management in Engineering, Vol. 33 No. 6, pp. 05017006-1-05017006-11.

Anderson, E.W., Fornell, C. and Lehmann, D.R. (1994), "Customer satisfaction, market share, and profitability: findings from Sweden”, Journal of Marketing, Vol. 58 No. 3, pp. 53-66.

Andrews, K.R. (1980), The Concept of Corporate Strategy, Richard D. Irwin, IL, Homewood.

Ansoff, H. (1958), “A model for diversification”, Management Science, Vol. 4 No. 4, pp. 392-414.

Ashmawi, K., Hadidi, L.A., Assaf, S., Tuffaha, F.M. and Al-Ofi, K. (2018), "Risk assessment and allocation in the contract for public works used in Saudi Arabia construction industry", Cogent Engineering, Vol. 5 No. 1, pp. 1-21.

Bolstein, A.R. and Crow, M. (2008), "Statistical formulas and citations for EPA's 2007 ERP sample planner and ERP results analyser", EPA Contract Number EP- W-04-023, Work Assignment 3-61, May 12.

Burnside, K. and Westcott, T. (1999), "Market trends and developments in QS services", in Baldry, D. and Ruddock, L. (Eds), Proceedings of COBRA, 1999: The Challenge of Change: Construction and Building for the New Millennium, 1-2 September, RICS, Salford, pp. 88-102.

Cao, Y. and Gruca, T.S. (2005), "Reducing adverse selection through customer relationship management", Journal of Marketing, Vol. 69 No. 4, pp. 219-229.

Cartlidge, D. (2009), Quantity Surveyor's Pocket Book, 1st ed., Butterworth-Heinemann, Oxford.

Cheah, C.Y.J., Kang, J. and Chew, D. (2007), "Strategic analysis of large local construction firms in China", Construction Management and Economics, Vol. 25 No. 1, pp. 25-38.

Darko, E. and Löwe, A. (2016), "Ghana's construction sector and youth employment", Overseas Development Institute (ODI), ODI Working Paper, available at: www.odi.org/sites/odi.org.uk/ files/resource-documents/10787.pdf (accessed 29 August 2018).

Drew, D.S., Ho, L.C.Y. and Skitmore, M. (2001), "Analyzing a consultant's competitiveness in two envelope fee tendering", Construction Management and Economics, Vol. 19 No. 5, pp. 503-510.

Frei, M. (2010), "Implications of the global financial crisis for the quantity surveying profession", The Building Economist, available at: https://search.informit.com.au/documentSummary;dn= 591858680659485;res=IELBUS (accessed 28 June 2017).

Ganiyu, B.O., Oyewobi, L.O., Nwokobia, L. and Sulaiman, B. (2012), "Diversification and performance of quantity surveyors in Nigerian construction industry", Proceedings of RICS COBRA 2012 Conference, 11th-13th September 2012, AZ State University, NV.

Ghana Statistical Service (2017), "Provisional 2016 annual gross domestic product", available at: www. statsghana.gov.gh/docfiles/.../Annual_2016_GDP_April\%202017_Edition.pdf (accessed 29 August 2018).

Gluck, F.W. (1985), “A fresh look at strategic management”, Journal of Business Strategy, Vol. 6 No. 2, pp. 4-19.

Hanid, M., Zakaria, N., Karim, S.B.A., Stabal, L.A.W. and Lee, T.Y. (2007), "Beyond the tradition: venturing quantity surveying services in the non construction sectors", A Paper presented at Quantity Surveying International Conference, 4-5 September 2007, Kuala Lumpur. 
Hoxley, M. (2008), "Questionnaire design and factor analysis", in Knight, A. and Ruddock, L. (Eds), Advanced Research Methods in the Built Environment, Wiley-Blackwell, Chichester.

Jang, Y. (2012), "Does international corporate diversification improve access to capital?", Working Paper, The Ohio State University, available at: production.wordpress.uconn.edu/.../DoesInternational-Corporate-Diversification.pdf (accessed 26 November 2017).

Jennings, M.J. and Betts, M. (1996), "Competitive strategy for quantity surveying practices: the importance of information technology", Engineering, Construction and Architectural Management, Vol. 3 No. 3, pp. 163-186.

Kaklauskas, A., Kelpsiene, L., Zavadskas, E.K., Bardauskiene, D., Kaklauskas, G., Urbonas, M. and Sorakas, V. (2011), "Crisis management in construction and real estate: conceptual modeling at the micro-, meso- and macro-levels”, Land Use Policy, Vol. 28 No. 1, pp. 280-293.

Kim, C., Kyung Hoon Yang, K.H. and Kim, J. (2008), "A strategy for third-party logistics systems: a case analysis using the blue ocean strategy", Omega, Vol. 36 No. 4, pp. 522-534.

Kim, W.C. and Mauborgne, R.A. (2014), Blue Ocean Strategy, Expanded Edition: How to Create Uncontested Market Space and Make the Competition Irrelevant, Harvard Business Review Press.

Kim, W.C. and Mauborgne, R. (2015), Blue Ocean Strategy, How to Create Uncontested Market Space and Make Competition Irrelevant, Harvard Business Review Press, Boston, MA.

Larsen, N. (2010), "Market segmentation - a framework for determining the right target customers. Aarhus School of Business", available at: pure.au.dk/portal/files/11462/ba.pdf (accessed 27 June 2017).

Lee, C.C., Perera, S. and Hogg, K. (2013), "An analysis of early career training requirements for quantity surveying professionals”, International Journal of Strategic Property Management, Vol. 17 No. 2, pp. 161-173.

Lette, A., Ambelu, A., Getahun, T. and Mekonen, S. (2018), "A survey of work-related injuries among building construction workers in southwestern Ethiopia", International Journal of Industrial Ergonomics, Vol. 68 No. 1, pp. 57-64.

Ling, F.Y.Y., Ning, Y., Chang, Y.H. and Zhang, Z. (2018), "Human resource management practices to improve project managers' job satisfaction", Engineering, Construction and Architectural Management, Vol. 25 No. 5, pp. 654-669.

Littler, D. (2015), Focus Strategy, John Wiley and Sons.

Mzyece, M.D., Zulu, M.E., Nyirenda, M.L. and Manase, D. (2010), "Beyond the tradition: extending quantity surveying services in the zambian mining sector", Proceedings of 5th Built Environment Conference, Vol. 18, p. 20, available at: www.irbnet.de/daten/iconda/CIB_DC22745. pdf (accessed 26 June 2017).

Naoum, S.G. (2013), Dissertation Research and Writing for Construction Students, 3rd ed., Routledge, London.

Ofori, G. and Toor, S.R. (2012), "Role of leadership in transforming the profession of quantity surveying", Construction Economics and Building, Vol. 9 No. 1, pp. 37-44.

Oke, A.E. (2018), "Bonding capability of Nigerian contracting firms", Engineering, Construction and Architectural Management, Vol. 25 No. 6, pp. 707-720.

Olanrewaju, A. and Anahve, P.J. (2015), "Duties and responsibilities of quantity surveyors in the procurement of building services engineering”, Procedia Engineering, Vol. 123 No. 1, pp. 352-360.

Olatunde, J. (2006), "New opportunities for quantity surveyors in Nigeria business environment", NIQS 22nd Biennial Conference, 22nd-25th November, 2006, Calabar.

Olatunji, O.A. (2007), “ Conflict of interest within construction practitioners: quantity surveying, case study”, Surveying and Built Environment, Vol. 18 No. 1, pp. 35-50.

Olatunji, O.A. and Ogunsemi, D.R. (2006), "Exploring the ethical perceptions of various levels of quantity surveying staff in Nigeria", Proceeding of Australia Universities Building Educators' Association Conference 2006, Sydney. 
Olawale, A. (2006), "The quantity surveyor in highway development", Proceedings of 22nd Biennial Conference of the Nigerian Institute of Quantity Surveyors, 22-25th November, 2006, Calabar.

Opoku, A., Ahmed, V. and Akotia, J. (2016), "Choosing an appropriate research methodology and method", in Ahmed, V., Opoku, A. and Aziz, Z., (Eds), Research Methodology in the Built Environment: A Selection of Case Studies, Routledge, New York, NY, p. 34.

Owusu-Manu, D., Badu, E. and Otu-Nyarko, D. (2010), "Corporate social responsibility: perspectives of the Ghanaian construction industry", International Journal of Project Planning and Finance, Vol. 1 No. 1, pp. 60-83.

Owusu-Manu, D., Edwards, D.J., Holt, G.D. and Prince, C. (2014), "Industry and higher education integration: a focus on quantity surveying practice", Industry and Higher Education, Vol. 28 No. 1, pp. 27-37.

Pervan, M., Pervan, I. and Ćurak, M. (2017), "The influence of age on firm performance: evidence from the croatian food industry", Journal of Eastern Europe Research in Business and Economics, Vol. 2017 No. 1, pp. 1-10.

Porter, M.E. (1986), Competitive Strategy: Techniques for Analysis of Industry and Competition, Campus, Rio de Janeiro.

Porter, M.E. (1989), Competitive Advantage, Rio de Janeiro, Campus.

Porter, M.E. (2000), "Attitudes, values, beliefs, and the microeconomic of prosperity", in Harrison, L.E and Huntington, S.P. (Eds), Culture Matters, Basic Books, New York, NY, pp. 14-28.

Rahim, F.A., Abd-Rahman, H., Wang, C., Othman, N.D. and Zainon, N. (2013), "Quantity surveying firms survival of fast developing economy", Journal of Surveying, Construction and Property, Vol. 4 No. 1, pp. 1-18.

Rumelt, R. (1974), Strategy, Structure and Economic Performance, Harvard University Press, Cambridge.

Sala-I-Martin, X., Doppelhoffer, G. and Miller, R. (2004), "Determinants of long-term growth: a bayesian averaging of classical estimates (BACE) approach”, American Economic Review, Vol. 94 No. 4, pp. 813-835.

Sala-I-Martin, X., Crotti, R., Di Battista, A., Drzeniek Hanouz, M., Galvan, C., Geiger, T. and Marti, G. (2015), "Reaching beyond the new normal: findings from the global competitiveness index 2015-2016", in Schwab, K. (Ed.), The global competitiveness report 2015-2016, World Economic Forum, Geneva.

Seeley, I.H. (1997), Quantity Surveying Practice, 2nd ed., Antony Rowe, London.

Seeley, I.H. and Murray, G. (2001), Civil Engineering Quantities, 6th ed., Palgrave.

Sexton, M. (2007), “Axiological purposes, ontological cages and epistemological keys”, PhD Thesis, Research Institute for the Built and Human Environment, University of Salford.

Smith, P. (2004), "Trends in the australian quantity surveying profession: 1995-2003", Project Management Department, University of Technology, available at: www.icoste.org/korev2004a. pdf (accessed 29 December 2016).

Tanwar, R. (2013), "Porter's generic competitive strategies", IOSR Journal of Business and Management, Vol. 15 No. 1, pp. 11-17.

Taylor, D.H. (2005), "Value chain analysis: an approach to supply chain improvement agri-food chains", International Journal of Physical Distribution and Logistics Management, Vol. 35 No. 10, pp. 744-761.

Teece, D.J. (1996), "Firm organization, industrial structure, and technological innovation", Journal of Economic Behavior and Organization, Vol. 31 No. 2, pp. 193-224.

The Canadian Institute of Quantity Surveyors (2002), Quantity Surveying and Cost Consulting Services, 4th ed., Canadian Institute of Quantity Surveyors.

Treacy, M. and Wiersema, F. (1993), "Customer intimacy and other value disciplines", Harvard Business Review, Vol. 71 No. 1. 
Treacy, M. and Wiersema, F. (1995), The Discipline of Market Leaders: Choose Your Customers, Narrow Your Focus, Dominate Your Market, Addison-Wesley.

Underwood, J.D. (2013), Competitive Intelligence for Dummies, John Wiley and Sons, NJ.

Waller, M.A., Dabholkar, P.A. and Gentry, J.J. (2000), "Postponement, product customization, and market oriented supply chain management”, Journal of Business Logistics, Vol. 21 No. 2, pp. 133-161.

Weber, W. and Polo, E.F. (2010), "Evolution of generic competitive strategies and the importance of Michael E. Porter", Revista de Gestão, Vol. 17 No. 1, pp.99-117.

\section{Further reading}

Aaker, D. (1980), Marketing Research: private and Public Sector Decisions, Wiley, New York, NY.

Adesi, M., Owusu-Manu, D. and Murphy, R. (2018), "Strategic competences for pricing quantity surveying consultancy services", Engineering, Construction and Architectural Management, Vol. 25 No. 3, pp. 458-474.

Kotler, P. (1997), Marketing Management: analysis, Planning, Implementation and Control, Prentice Hall, NJ.

Kulasekara, G., Jayasena, H.S. and Ranadewa, K.A.T.O. (2013), "Comparative effectiveness of quantity surveying in a building information modelling implementation", The Second World Construction Symposium: Socio-Economic Sustainability in Construction, 14-15, June 2013, Colombo.

Murphy, R. (2013), "Strategic planning in construction professional service firms: a study of irish QS practices", Construction Management and Economics, Vol. 31 No. 2, pp. 151-166.

Oechler, E., Molenaar, K.R., Hallowell, M. and Scott, S. (2018), "State-of-practice for risk-based quality assurance in state departments of transportation", Engineering, Construction and Architectural Management, Vol. 25 No. 7, pp. 958-970.

Umeokafor, N. (2018), "An investigation into public and private clients' attitudes, commitment and impact on construction health and safety in Nigeria", Engineering, Construction and Architectural Management, Vol. 25 No. 6, pp. 798-815.

\section{Corresponding author}

Michael Adesi can be contacted at: adesimichael@yahoo.com

For instructions on how to order reprints of this article, please visit our website: 